\title{
The Change of Words Sounds of Indonesian Declarative Utterance by Autistic Children
}

\author{
Ika Septiana \\ Univeristas Negeri Surabaya (Unesa), Surabaya, Jawa Timur, Indonesia \\ Universitas PGRI Semarang, Jawa Tengah, Indonesia \\ Bambang Yulianto \\ Univeristas Negeri Surabaya (Unesa), Surabaya, Jawa Timur, Indonesia \\ Kisyani Laksono \\ Univeristas Negeri Surabaya (Unesa), Surabaya, Jawa Timur, Indonesia
}

\begin{abstract}
Every child has language proficiency and they can utter words or sentences as they wish. Every child's utterance has uniqueness and meaning that needs to be understood by people around them. The same thing is experienced by autistic children. These children need special attention. Sometimes, utterances by autistic children is hard to be understood by the adults. In addition, the utterances can be less clear due to different sound of the actual words. Therefore, the adults cannot understand what these children say. The adults' understanding can help the development of language proficiency of autistic children. The purpose of this paper is to describe the change of sound of Indonesian utterances by autistic children. The data of this research were collected with observation and interview. The data were collected by recording the utterances of autistic children. The data of this research were Indonesian sentences. The resource of the data was utterances of autistic children. The object of this research was the change of sound of Indonesian utterances. The data were analyzed by using match method that is phonetic-articulatory with basic technique of selecting certain element.
\end{abstract}

Keywords: change of sound; utterance; Indonesian language; autistic children

DOI: $10.7176 /$ JLLL/61-12

Publication date:October $31^{\text {st }} 2019$

\section{Introduction}

Compared to the adults' utterance, children's utterance is specific. This special characteristic can be spotted on the short and simple utterance. The simplicity can be in the form of incomplete sentence or shortened phrase or word (Yulianto, 2009, p. 1). Gozali's research (1987) (in Yulianto, 2009, p.1) showed that children produce utterance which is different from the adults' utterance regarding sound of language, word selection, word from, or the sentence structure.

There are autistic children who can use language but still need the help of others. Although the language they use is still less clear or less perfect, these children have tried to express what they want to convey. In addition to children capable of speaking with others, there are also autistic children who have been able to read. It does not happen to every autistic child. This phenomenon depends on condition and characteristic of the autistic child.

Autistic children are capable of communicating with discourse as if they give sermon. The utterance of autistic children is often in the form of monologue about something which is very important for them. Autistic children do not have capability to understand the others' opinion and they consider that conversation is two-directional activity (Bonnice, 2009, p. 34).

Autistic children have specific and unique utterance so that they have intonation which changes once in a while. Autistic children can use language and speak with others. In speaking activity, autistic children can produce command statement and question for others. Teacher and parents teach autistic children to be confident, trust others and dare to express opinion to others.

Every child is encouraged to be able to cooperate with others, trust each other, identify and clarify dilemmatic situation when they are at school or at home. The children also develop moral rationalizing skill and skill to accept others' opinion in discussion. The children are encouraged to be able to make question. In this case, there are language proficiencies which are developed, they are basic skill of scrutinizing (listening) and communicating (Zuchdi, 2009, p. 65).

Tone or intonation which changes when uttering will produce various utterances. People use various intonation to convey meaning so that the sentence they use seems different and has different meaning. Although the context is clear, it needs deep understanding to understand the meaning of the utterance. According to Cummings, (2010, p. 37--44), context idea is so important for pragmatic so that it needs understanding in every utterance. According to its nature, context is wide concept which involves physical, linguistic, epithetic and social 
elements. Conversation often takes place in the context of manifestation of pragmatic language skill. The speaker cannot convey message well unless there is respondent who can understand the meaning of the utterance. Therefore, the number of pragmatic concept depends on the conversation structure.

Autistic children have slower speaking development compared to normal children at their age. If the autistic children can speak, their speaking is usually inconsequential and even the language they use is often called as 'alien' language. Therefore, they speak not to communicate; they just produce meaningless and repetitive sound. Autistic children find difficulty in reciprocal communication and it is difficult for them to imitate the behavior of others (Subyantoro, 2013, P. 97).

Every child has a way of expressing something thought or perceived. In children with autism there is a way to express expression and feelings even though sometimes have difficulty. There are several ways that autistic children do when expressing themselves is by babbling or telling excessive speech or no interest when communicating with others. Various kinds of speech spoken by children with autism even though the speech is less meaningful or excessive (Septiana, 2017, p. 23--24).

Pragmatic-marking intonation is very difficult but it highly depends on the speaker's perception on how important the marker is. The discourse marker which serves to refer to the shared knowledge between the speaker and listener has two or three possible tones. If the speaker assumes that he/she receives various shared information, and they do not need answer, the falling tone is used. If the speaker wants to get response from the recipient in order to check shared knowledge, compound increase or decrease will be used (Komar, 2007, P. 43-$55)$.

Underlying factors which might influence child language development i.e. age, gender and socio-economic status (maternal education) are also examined (Ononye, 2017). children use a lending strategy to create a relative clause structure. It turns out that relative clauses are complicated verses derived from children over other syntactic structures (Norsofiah, 2016, p. 163)

The utterance of autistic children on this paper is Indonesian utterance. The children uttered naturally according to what they want to utter so that there is interaction between children (speaker) and recipient.

\section{Methods}

This research used qualitative approach to describe the pattern of Indonesian sentence intonation by autistic children based on pragma-linguistic study. Therefore, this research was categorized as descriptive-qualitative research. The data was collected by recording and noting the utterance of autistic children. The data which was collected is Indonesian utterance. The data of this research was Indonesian language.

The resource of this research was utterance of autistic children who are now studying at SDLB (Elementary School for Children with Special Needs). The sources of this research data are four male autistic children categorized as mild autism, at the age of 11 to 15 . The object of this research is the change of sound of Indonesian utterance by autistic children. The data was analysed with match method that is phonetic-articulatory method with basic technique of selection of certain element.

The method which was used in this research was linguistic method which was proposed by Sudaryanto (2001) in his book entitled "Metode dan Aneka Teknik Analisis Bahasa". This method uses match method with determiner device of speaking organ and phonetic-articulatory method. Match method use determiner device which is outside, separated, and is not the part of the related language.

The methods which were used to collect data were scrutinizing, speaking and observation. The data was collected by scrutinizing utterance of autistic children and making conversation with them.

\section{Result and Discussion}

Children uttered sentence naturally and spontaneously. This utterance is natural utterance which was obtained from autistic children through question-answer activity or direct communication with the children. The data which was obtained was declarative sentence which contained change of sound on the word uttered by autistic children. The change of sound of Indonesian sentence by autistic children which was obtained was declarative sentence. The change of sound on a word can occur on the following sentence and the other sentence which used the word so that it was obtained a declarative sentence in the form of single sentence and word combination sentence.

The following is the words uttered by autistic children which have change of sound in Indonesian sentence. 
Table 1

The change of word in Indonesian declarative sentence

\begin{tabular}{cc}
\hline Original Words & Words After Change of Sound \\
\hline Matras (mattress) & matlas \\
Masjid (the mosque) & mesjid \\
Sebel (resentful) & nyebelin \\
Jemput (pick-up) & jemut \\
Sedap (delisious) & sedep \\
Tidak (no) & gak \\
Enggak (noper) & gak \\
Dengar (dear) & denger \\
Diam (shut up) & diyem \\
Saja (only) & aja \\
Minggir (move aside) & miger \\
\hline
\end{tabular}

Declarative sentence produced by autistic children was in the form of single sentence and word combination sentence. In this research, single sentence means a sentence which consists of one word which occurs in every utterance of autistic children. Although it is only a word, it is still called sentence since it has intonation and meaning. Word combination sentence means sentence which consists of two words or more which are combined in one sentence and has final intonation. Single-word sentence and word combination sentence produced by autistic children are very various.

(1) Matlas.

$2 \quad 1 \mathrm{t} \#$

(2) Nih matlas.

$21 / 2$ 1t\#

(3) Gonta ganti matlas.

$2 \quad 2 \quad 23 \quad 231 t \#$

(4) Kasur matlas.

2 - $\quad 1 \mathrm{t} \#$

(5) Matlas kasur.

2- $\quad 1 \mathrm{t} \#$

(6) Matlasnya kasur.

2 - $\quad 1 \mathrm{t} \#$

The intonation patterns of data (1) - (6) ended with low pattern (1t\#). Each utterance has variety intonation pattern. This variety is located on the single-word sentence when the children uttered declarative sentence. The intonation pattern of declarative sentence was the same (4) - (6), that is 2- 1t. meanwhile, data (2) showed emphasis on word "nih" with intonation pattern 21/. The word matlas has different pattern according to its location. The intonation pattern of the word matlas which was located on the end of sentence has similar intonation pattern (21t). Meanwhile, the word matlas which was located on the beginning of sentence has intonation pattern 2-(22).

Data (1) - (6) was uttered uniquely. Actually, the children intended to say "matras" instead of "matlas". Children uttered declarative sentence in the form of single-word sentence and word combination sentence. The single-word sentence "matlas" was combined with some words to form combination word sentence such as "nih matlas", "gonta ganti matlas", "kasur matlas", "matlas kasur", and "matlasnya kasur".

These utterances were twaddle of autistic children. The children uttered declarative sentence spontaneously pursuant to what is in their heart and mind. In addition, the uniqueness was also found the sound of the word "matras". There was change of sound on this word. When these children sad "matras", the utterance that came out s "matlas", instead of "matras". The sound of [r] changed into [1]. 
On data (3), autistic children said repetitive word such as "gonta-ganiti". The word "gonta-ganti" is the product of morphological repetition of the basic word "ganti." After the repetition, the sound became "gontaganti". There was a change of sound from [a] into [o]. therefore, the sound became "gonta-ganti".

The above explanation is as explained by Septiana (2007, p. 364--371). The utterance is an autism children chatter. The child expresses declarative sentence spontaneously according to the one in his heart and mind. In addition to this uniqueness there is a sound spoken on the word "mat". Part of the sound changes when the autistic child spoke "matras". The lines that appear are not "matras" but "matlas". This change of sound was caused by several factors. The children found difficulty in producing the sound of $[\mathrm{r}]$ in the word of "matras". The sound [r] has similar phonetic feature to that of sound [1] since [r] and [1] are located on the same row that is alveolar. The sound [1] is the partner of sound [r] which has phonetic similarity. The sound [r] is close to sound [1] since sound [1] is lateral and [r] is trill. Therefore, the utterance spoken by and heard from these children on the word [matras] became [matlas].

Data (1) - (6) was uttered by autistic children with decreasing final intonation. Utterance (3) has emphasis when the children said the sentence. The emphasis was on the syllable gon ta-gan $\underline{\text { ti }} \underline{\text { mat }} \underline{\text { las. The }}$ intonation which occurred when the word was spoken was low intonation that is $1 \mathrm{t}$ which ended the sentence. The sentence was declarative sentence in the form of word combination sentence from the single word "matlas".

Utterance (3) has the meaning to inform others. The word "gonta-ganti" which was spoken by autistic children referred to the call or name of a person. Data (3) showed the answer by autistic children concerning the researchers' question. The answer, data (3), had the meaning that the children still knew whom they were talk to although they only meet several times.

$$
\begin{gathered}
\text { Itu mesjid itu. } \\
2-\quad 1 t \# \\
\text { [Itu masjid itu] }
\end{gathered}
$$

$$
\begin{aligned}
& \text { Mesjid itu mesjidnya. } \\
& 2-\quad 1 / 2-\quad 1 \mathrm{t} \#
\end{aligned}
$$

The intonation pattern of sentence (7) was symbolized with 2-1t\#. The intonation pattern of sentence (8) was symbolized with 2-1/2-1t\#. The sentence (7) and (8) contained repetition of different words. In sentence (7), there was repetition of the word "itu". Meanwhile, sentence (8) has repetition of word "masjid". Although there was repetition of different words, the purpose of the utterance was the same, that is to inform about "masjid" (mosque).

Sentence (7) was the answer of the question "Tahu dari mana azan?" The children's answer was pursuant to the sentence (7). It means that children knew and capable of azan from mosque. The children heard azan from mosque near their house. Although they never go to mosque, they often hear azan so they can pronounce azan.

On utterance of sentence (7), the word "masjid" was spoken by children as "mesjid". The sound [a] changed into $[\therefore]$.

masjid - mesjid

$$
\begin{aligned}
& {[\mathrm{a}] \quad[\therefore]} \\
& -a-\sim-\therefore-
\end{aligned}
$$

There was change of the sound [a] into $[\therefore]$. The sound $[\mathrm{a}]$ changed into $[\therefore]$ and these sounds have phonetic similarity. These sounds are also located on the same sound column. Based on the position of tongue [low or high], the sound $[\mathrm{a}]$ is low and the sound $[\therefore]$ is moderate. Based on the tongue movement [forward or backward], the sound $[\mathrm{a}]$ is front sound and the sound $[\therefore]$ is middle sound.

There was tentative juncture on sentence (8) on the word "itu" (21/) which was then followed by final juncture with $21 \mathrm{t} \#$ pattern. Therefore, this part has final decreasing intonation which ended the sentence. Tentative juncture was on the middle of sentence and marked temporary juncture and was followed by another intonation.

$$
2 \stackrel{2}{\text { Nyebelin. }} \text {. }
$$

(10) Lagi ngomong yang nyebelin.

$$
2 \text { - } 1 / 21 / 231 \mathrm{t} \#
$$


(11) Kamu nyebelin sih.

2 2/ 2 - 3t\#

The intonation pattern of sentence (9) was symbolized with $231 \mathrm{t}$. The intonation pattern of sentence (10) was symbolized with $2-1 / 21 / 231 \mathrm{t}$. The intonation pattern of sentence (11) was symbolized with 22/2 23 t\#. Sentence (9) is single-word sentence. Sentence (10) and sentence (11) are word combination sentence.

The word "nyebelin" on sentence (9) - (11) was "sebel" which means upset due to state of unhappy, disappointed, mad at others or themselves. The children often say the word "nyebelin." It can be seen on sentence (9)-(11). The children did not only say it once. Although this word is not the actual Indonesian word, the meaning of this word is similar to that of the word sebel in Indonesian language. This word was spoken in some word combination sentences.

$$
\begin{array}{ll}
{[\text { sebel] }} & \text { [nyebelin] } \\
{[s . \therefore b .: l]-} & {[\propto .: b . \therefore \text { lin] }} \\
{[\mathrm{s}]-[\propto]} & \\
\text { s- } \sim \propto- &
\end{array}
$$

The topic of utterance (9) - (11) is bad thing which made someone disappointed. The meaning of utterance (10) and (11) is different. On sentence (10), the speaker expressed bad thing which made someone angry. In this sentence, the subject vanished. If the subject appears, the sentence will be as follows:

(10b) $\frac{\text { Danie lagi ngomong yang nyebelin. }}{\mathrm{S}}$

(11c) $\frac{\text { Kamu }}{\mathrm{S}} \frac{\text { nyebelin sih. }}{\mathrm{P}}$

In sentence (10b), the vanished part appeared. The doer or subject of the sentence appeared and made the meaning clear. It is different from sentence (11). In this sentence, the one who made angry is someone else or the recipient. This is because the doer or subject is in the sentence, as you can see in sentence (11c). In sentence (11), there is addition of word "sih". This word serves as addition or emphasizer in sentence. This word has purpose to inform others. This word is located at the end of the sentence.

(12) Mau jemut bu Anna ngajar.

$$
\text { 2- } \quad 3 / 2-\quad 322 \mathrm{t} \#
$$

[Mau jemput, bu Ana ngajar.]

(13) Mau jemut diantar pak Santoso.

$$
\begin{aligned}
& \text { 2- 3/2- } 32 \text { 2t\# } \\
& \text { [Mau jemput, antar pak Santoso.] }
\end{aligned}
$$

Sentence (12) and (13) are word combination sentences which have similar intonation pattern. The intonation pattern of these sentences is $2-3 / 2-322 \mathrm{t}$. There was increasing emphasis in the final syllable in the word jemput and there was juncture when the word was spoken.

The word jemput was spoken less perfectly so that there was reduction of cluster or series of sounds. The double sound in the middle of the sentence became single sound due to vanished first sound. It means, one of sounds in the middle of word vanished. In the first syllable, the sound of the end of this syllable vanished when the children said the word jemput. Therefore, there was only one syllable which appeared.

$$
\begin{array}{rrrr}
\text { [jemput] - } & & {[\text { jemut }]} \\
\text { [jempUt] } & & {[\mathrm{j} \therefore \text { mUt }]} \\
{[\mathrm{p}]} & - & {[\varnothing]} \\
-\mathrm{p}- & \sim & -\varnothing-
\end{array}
$$

There was emphasis at the end of word when the word jemut was spoken. The emphasis was on the final syllable, "Ut". There was increasing emphasis when the children said the word so that there was tentative juncture although it was temporary. 
(14) Nasi, sayur, sama tempe sedep.

$22 / 23 / 2-\quad 2 \mathrm{t} \#$

The intonation pattern of sentence (14) was symbolized with 22/ 23/2- $2 \mathrm{t}$. In sentence (14), there was similar juncture. The juncture of this utterance was tentative juncture. The juncture which was temporary was then followed by other words in a series of sentences. There were two tentative junctures in the sentence. There was increasing juncture on the final syllable. This sentence was uttered with juncture in the middle of the sentence. This sentence informed others.

In sentence (14), there was utterance of word which was less appropriate with Indonesian vocabulary. The word "sedap" was uttered as "sedep". There was change of sound $[$ a] into $[\therefore]$.

$\begin{array}{ccc}{[\text { sedap] }} & - & {[\mathrm{sedep}]} \\ {[\mathrm{s} \therefore \mathrm{dap}]} & - & {[\mathrm{s} \therefore \mathrm{d} \therefore \mathrm{p}]} \\ {[\mathrm{a}]} & - & {[\therefore]}\end{array}$

This change of sound was similar to the change in sentence (14). These two sentences had the change of sound $[\mathrm{a}]$ into $[\therefore]$. This is because the sound $[\therefore]$ and $[\mathrm{a}]$ have phonetic similarity. These sounds are located on the same sound column. Based on the position of tongue [low or high], the sound [a] is low sound and $[\therefore]$ is moderate sound. Based on the movement of tongue, the sound $[\mathrm{a}]$ is front sound and $[\therefore]$ is middle sound.

Sentence (14) was word combination sentences which were spoken by the children spontaneously. Sentence (14) is the answer of a question.

(14b) BI : Ismail makan apa?

IN : Nasi, sayur, sama tempe sedep.

The children answer question pursuant to what is inside their heart and mind. The sentence can be understood although it is less appropriate with the question.

There is change of sound on some words in Indonesian declarative sentence. This change forms patterns of change of language sound, such as substitution pattern, omission pattern and addition pattern.

3.1 Substitution Pattern

The substitution pattern of Indonesian declarative utterance of autistic children contains some sound which cause the change of sound. The process of change of sound on this utterance is on the word 'matras'.

(a) Reference word

Phonological rule:

Change of sound of consonant $/ \mathrm{r}$ /

(lateralization)

Intonation pattern

Change of sound

Final representation

(data 1--6) [matras $]$

$[$ matlas $]$

[matras $]-[$ matlas $]$

[r] - [1]

$-r-\sim-1-$

[matlas]

The substitution pattern on the word "matras" contains sound which is substituted in the middle of the word. Type (a) shows liquid nonliteral / $r /$ at the beginning of syllable which changes into lateral $/ 1 /$. This substitution takes place at the beginning of the syllable that is the first letter of the second syllable [mat-ras]. The change of sound takes place at the pronouncing of the same sound in repeteadly on the same word utterance.

In addition to the word "matras", the word "sebel" also has change in the utterance of autistic children.

(b) Reference word

Phonological rule:

Suffix addition (affixation)

Change of first syllable

Phonetic representation

Intonation pattern

Change of sound [sebel]

[sebelin]

[nyebelin]

[oceb $\therefore$ lin]

(231)

[sebel] - [nyebelin] 
Final representation

$$
\begin{aligned}
& {[\mathrm{s}] \quad-\quad[\mathrm{ny}]} \\
& -\mathrm{s}-\sim-\propto- \\
& {[\text { nyebelin] }} \\
& \text { (data 9--11) }
\end{aligned}
$$

Based on type (b), phonologically, the reference word "sebel" on the utterance of autistic children has phonological rule of addition (affixation), that is suffix and there is change of sound on the first syllable. The substitution pattern on word "sebel" is located on the sound of the first word. The sound /s/ on the beginning of the word turns into /ny/. This substitution is located on the beginning of the first syllable, that is the first letter in the syllable [se-bel]. The change of sound is located on the repeated pronunciation of the same sound on the utterance of the same word when the children uttered the word "sebelin".

Type (b) of the change of sound on word [sebel] into [nyebelin] is caused by the addition of suffix (-in) (therefore, the word becomes [sebelin]) and the initial change of [s] into nasal voice [ $\propto$ ]. The change of [sebel] into [nyebelin] is on data (9-10). The pattern of intonation of [nyebelin] is symbolized by 231 at the end of sentence and 222 in the middle of sentence.

The pattern of substitution of sound on the first syllable also occurred on the word "mesjid". Although the change is on the first syllable, there is different pattern of substitution on the change of sound of Indonesian declarative sentence. The word "masjid" has change of sound of the first syllable on the second letter, that is [masjid].

(c) Reference word

Phonological rule:

Substitution of middle vocal

Intonation pattern

Change of sound

Final representation

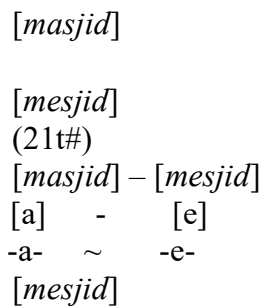

(data 7, 8)

The sound /a/ turned into $/ \therefore /$. This change is on the first syllable on the middle vocal. The change of sound occurred because both sound are front sound and non-round sound which are located on the same column. In addition, the letter /a/ is a vocal letter which is located between two consonants (KVK).

(d) Reference word

Phonological rule:

Substitution of middle vocal

Change of sound

Final representation

$$
\begin{aligned}
& \text { [sedap] } \\
& \text { [sedep] } \\
& \text { [sedap]-[sedap] } \\
& \text { [a] - [e] } \\
& \text {-a- } \sim \text {-e- } \\
& \text { [sedep] }
\end{aligned}
$$

In contrast to the change of sound of word "masjid" into "masjid which occurred on the first syllable, the change of sound /a/ into /e/ on the word "sedep" occurred on the second syllable. Therefore, the word becomes "sedep". The change of /a/ into /e/ in the word "mesjid" and the word "sedep" is located between two consonants (KVK). Letter e is vocal located between consonants on the syllable [dep].

The change of sound with pattern of substitution on the second syllable also occurred on the word "dengar". Autistic children uttered the word "dengar" as "denger" numerous times on Indonesian declarative sentence.

(e) Reference word

Phonological rule:

Substitution of sound

Change of sound

Final representation

$$
\begin{aligned}
& {[\text { dengar }]} \\
& {[\text { denger }]} \\
& {[\text { degar }]-[\text { denger }]} \\
& {[\mathrm{a}] \quad-\quad[\mathrm{e}]} \\
& -\mathrm{a}-\sim-\mathrm{e}- \\
& {[\text { denger }]}
\end{aligned}
$$

The change of sound /a/ into /e/ on the word "dengar" and the word "sedap" has change on the second syllable (which turn into word "denger" and "sedep" respectively). The change of /a/ into /e/ in words "masjid", "sedep" 
and "denger" is in between two consonants. However, the words "sedep" and "denger" have different structure. The vocal in the word "sedep" is in between two consonants (KVK) meanwhile the vocal in the word "denger" is in between consonants with pattern KKVK.

\subsection{Omission Pattern}

Utterance of Indonesian declarative sentence by autistic children has sound which is omitted. Therefore, this utterance has change of sound which is different from the original word or Indonesian basic word. This change of sound is categorized as omission pattern. This pattern includes omission of syllable, omission of final consonant and omission of vocal.

(f) Reference word

Phonological rule:

Reduction of initial consonant

Final representation

Intonation pattern [jemput]

[jemut]

[jemut]

(23)

(data 12,13)

The change of sound on the word "jemput" into "jemut" is categorized as omission pattern of initial consonant which is located on the beginning of the second syllable. The consonant which is omitted is $/ \mathrm{p} /$. Therefore, the sound of $/ \mathrm{p} /$ did not occur when the children uttered the word and the word which occurred was "jemut".

(g) Reference word

[saja]

Phonological rule:

Reduction of initial consonant [aja]

Final representation

$[$ aja

\subsection{Omission and Substitution Pattern}

The utterance of autistic children also has more than one phonological process, that is the change of sound because of omission pattern and substitution pattern. The omission pattern and substitution pattern occurred on the utterance of the word "minggir" which changed into "miger'

(h) Reference word

Phonological rule:

Reduction of double consonant

Substitution of middle vocal

Final representation
[minggir]
[migir]
[miger]
[miger]

This change of sound is categorized as omission pattern of double consonant $/ \mathrm{ng} /$ which is also categorized as nasal sound which is located in the middle of sentence. The omission of sound /ng/ which is categorized as double consonant on the first syllable caused the word uttered by the children to have change of sound which is different from the reference word or basic word. In addition to consonant reduction, there is also change of sound due to substitution of middle vocal on the second syllable /i/ with /e/ and therefore the utterance becomes "miger".

In addition to the word "minggir", there is also word "tidak" which has process of change of sound due to pattern of omission and substitution.

(i) Reference word

Phonological rule:

Reduction of first syllable

Omission of first syllable

Substitution of initial consonant

Phonetic representation

Final representation

[tidak]
[enggak]
$[$ dak]
$[$ gak]
$[$ ga? $]$
$[$ gak]

The change of sound "tidak" into "enggak" and "gak" is categorized as omission pattern of first syllable and substitution of initial consonant. The change of the word "enggak" is the process of change of sound with substitution pattern of the first syllable [ti] with [eng] and substitution of initial consonant on the word [dak] with [gak] and therefore it forms non-standard word "enggak". The change of sound on the word "gak" has two processes, they are omission of the first syllable [ti] and substitution of initial consonant on the word [dak] with [gak]. 
3.4 Addition Pattern

In the utterance of Indonesian declarative sentence by autistic children, there is word or sentence which has adjustment towards other sound and therefore there is addition of sound in the middle of sentence. The addition of sound can be addition of consonant sound or vocal sound. According to Yulianto (2009, p. 290), the adjustments of a sound towards another sound which comes before or after the sound can be vocal sound and consonant sound. This case occurred on the utterance of word "diam".

(j) Reference word

$[$ diam $]$

Phonological rule:

Addition of consonant [diyem]

\begin{tabular}{l} 
Final representation $\quad$ [diyem] \\
\hline
\end{tabular}

The change of sound of Indonesian declarative sentence "diam" into "diyam" is categorized as addition of initial consonant of the second syllable. There is addition of sound / $y /$ in the middle of word between vocal sound /ai/.

All of change of sound of utterance of autistic children which has been explained based on the pattern of change of sound above can be explained on the table of pattern of phonological change of sound.

Table 2

Pattern of phonological change of sound

\begin{tabular}{|c|c|}
\hline Pattern of Change of Sound & Utterance sample \\
\hline $\begin{array}{l}\text { 1. Pattern of Substitution } \\
\text { a.. substitution of consonant /r/ - / / } \\
\text { b. substitution of first syllable } \\
\text { c. substitution of middle vocal of first syllable } \\
\text { d. substitution of middle vocal of second syllable } \\
\text { 2. Pattern of Omission } \\
\text { a. Reduction of first consonant of second syllable } \\
\text { b. Reduction of first consonant of first syllable } \\
\text { 3. Pattern of omission and substitution } \\
\text { a. Reduction of double consonant and change of middle } \\
\text { vocal } \\
\text { b. Reduction of first syllable and change of first } \\
\text { 4. Pattern of addition } \\
\text { a. Consonant addition }\end{array}$ & $\begin{array}{l}{[\text { matras }] \sim[\text { matlas }]} \\
{[\text { sebel] } \sim[\text { nyebelin] }} \\
{[\text { masjid] } \sim[\text { mesjid }]} \\
{[\text { sedap] } \sim[\text { sedep }],} \\
{[\text { dengar }] \sim[\text { denger }]} \\
{[\text { jemput] } \sim[\text { jemut }]} \\
{[\text { saja }] \sim[\text { aja }]} \\
{[\text { minggir }] \sim[\text { miger }]} \\
{[\text { tidak] } \sim[\text { gak }]} \\
{[\text { diam }] \sim[\text { diyem] }}\end{array}$ \\
\hline
\end{tabular}

Based on the data above, there are autistic children's utterances which are less perfect. The imperfection of utterance of autistic children is the change of sound when they utter Indonesian sentence. The change of sound occurred on the word in a sentence. There is uttered word which is not appropriate with the pronunciation of Indonesian word and therefore the utterance becomes non-standard. In addition, when this word is uttered, it becomes less clear and even less understandable by the respondent.

Children's communication skill depends on their ability in understanding what others say and their speaking skill. The children who cannot understand what others say when communicating will face obstacle in communicating and they will find social obstacle. Difficulty to understand is caused by several things such as limited vocabulary that they have, respondent who speaks too fast, children who are raised in the family who use two languages at the same time and children's egocentric behaviour (Subyantoro, 2013, p. 113-114).

Not all autistic children's utterance cannot be understood. Actually, there are several utterances of autistic children which can be understood in communication activity. The children utter sentence pursuant to what they want to utter although sometimes the utterance is less understandable. To understand the utterance of autistic children, we need to understand their condition, characteristic and background. This is because characteristics of each child are different. Autistic children utter sentence based on an event that they have experienced and seen and therefore they use such event as conversation topic or something that they want to express or convey to others. 


\section{Conclusion}

The intonation of Indonesian sentence spoken by autistic children is determined based on Indonesian syllable. This method is intended to ease the determination of intonation pattern and to ease the reading of intonation in every word in a sentence. The intonation pattern of Indonesian sentence spoken by autistic children is marked with low intonation (1), moderate intonation (2), and high intonation (3). This pattern is used to mark the intonation pattern of Indonesian sentence.

The following is the data of change of sound of utterance of children with autism.

Table 3

The change of sound of utterance of children with autism

\begin{tabular}{|c|c|c|}
\hline Change of word & Change of sound & Correspondence \\
\hline [matras] - [matlas] & {$[\mathrm{r}]-[1]$} & $-r-\sim_{\operatorname{man}} \sim-1-$ \\
\hline [masjid]-[mesjid] & {$[\mathrm{a}]-[\mathrm{e}]$} & -a- $\sim-$-e- \\
\hline [sebel] - [nvebelin] & {$[\mathrm{s}]-[\mathrm{n}]$} & $\mathrm{s}-\sim \mathrm{n}-$ \\
\hline [iemput] - [jemut] & {$[p]-[\varnothing]$} & $-p_{-} \sim-\varnothing-$ \\
\hline [sadap] - [sadap] & {$[\mathrm{a}]_{\text {and }}-[\mathrm{e}]$} & -a- $\approx-\mathrm{e}-$ \\
\hline [enggak]-[gak] & {$[\eta]-[\varnothing]$} & әๆ- $\sim \quad \varnothing-$ \\
\hline [dengar] - [denger $]$ & [a] - [a] & $-a-\approx-e-$ \\
\hline [diam] $-[$ divem] & [a] - [yə] & -а- $\sim$ - -ур- \\
\hline [saja] $-[a j a]$ & {$[\mathrm{s}]-[\emptyset]$} & S- $\varnothing-$ \\
\hline [mingir] $-[$ miger $]$ & {$[y]-[\varnothing]$} & $\eta-\sim-\varnothing-$ \\
\hline
\end{tabular}

The change of sound of utterance of autistic children consists of four patterns; First, Substitution Pattern which includes a) substitution of consonant $/ \mathrm{r} /-/ 1 /, \mathrm{b}$ ) substitution of first syllable, c) substitution of middle vocal of first syllable, d) substitution of middle vocal of second syllable; Second, Omission Pattern which includes a) Reduction of initial consonant of second syllable, b) Reduction of initial consonant of first syllable; Third, Pattern of omission and substitution which includes a) Reduction of double consonant and substitution of middle vocal and b) Reduction of first syllable and substitution of first consonant; and Fourth, Addition pattern, with category of consonant addition.

The change of sound is caused by two factors, they are 1) the change of letter into another letter and 2) the vanished letter of uttered word which causes the word less appropriate with the real word. Based on the data of this research, it can be concluded that the change of sound of utterance of autistic children which often occurs is the change of sound [a] and sound [e].

The change of sound of utterance of autistic children needs attention from the others. The special attention for autistic children is very helpful to help their language proficiency development so that the children can understand the proper Indonesian language.

The success of the use of language on autistic children is not only the responsible of teacher or therapist; the role of parents is also crucial for the development of autistic children. The good communication with autistic children will help them to utter well and add their vocabulary. Parents, teacher or therapist can cooperate for the sake of language development of autistic children. In addition, they can also provide correction for autistic children when the children utter incorrect Indonesian sentence. Parents or teacher can ask the children to imitate the correct Indonesian sentence.

In order to be able to imitate the correct Indonesian sentence, the autistic children also need to be trained to concentrate and use eye contact between autistic children and the respondent. This is because when speaking with others, the autistic children do not concentrate and do not use eye contact with the respondent. They look downward or upward seeing surrounding things. They do not concentrate when they communicate. In addition, they act exaggeratedly and inconsistently.

\section{References}

Bonnice, Sherly. (2009). Anak yang Tersembunyi: Pemuda Autis. Klaten: PT Insan Sejati

Cummings, Lousise. (2010). Pragmatik Klinis. Yogyakarta: Pustaka Pelajar. 
Cummings, Lousise. (2010). Pragmatik: sebuah Perspektif Multidisipliner. Yogyakarta: Pustaka Pelajar.

Komar, Smiljana. (2007). The Interface between Intonation and Function of Discourse Markers in English. English Language Overseas Perspectives and Enquiries (ELOPE) Vol 4, No 1-2 (2007), 43-55. DOI: 10.4312/elope.4.1-2.43-55. Diperoleh dari http://revije.ff.uni-lj.si/elope/article/view/3323/3016 diunduh 30 September 2016)

Mintowati, Maria. (2009). Tuturan Penyandang Autis (Kajian Tindak Tutur Prinsip Kooperatif dan Strategis Komunikasi). (Disertasi tidak dipublikasikan). Program Studi Pendidikan Bahasa dan Sastra. Program Pascasarjana Universitas Negeri Surabaya.

Muslich, Masnur. (2008). Fonologi Bahasa Indonesia. Jakarta: Bumi Aksara

Norsofiah Abu Bakar, Rogayah A. Razak, and Lim Hui Woan (2016). Pemerolehan Klausa Relatif Dalam Kalangan Kanak-kanak Melayu: Satu Kajian Awal. GEMA Online ${ }^{\circledR}$ Journal of Language Studies. Volume 16(3), October 2016. http://ejournal.ukm.my/gema/article/view/10680/4815

Ononye, Chuka Fred. (2018). Linguistic Identity and the Stylistics of Nativisation in Adichie's Purple Hibiscus. GEMA Online ${ }^{\circledR}$ Journal of Language Studies. Volume $18 \quad$ No $4 \quad$ (2018). http://ejournal.ukm.my/gema/article/view/23651/8679

Septiana, ika, Bambang Yulianto, and Kisyani Laksono. (2017). Ketidakselarasan Tuturan Anak Autis. p. 23-34. E-Proseding Seminar Nasional Bahasa dan Sastra Indonesia dalam Konteks Global. Jember:Program Studi Pendidikan Bahasa dan Sastra Indonesia Fakultas Keguruan dan Ilmu Pendidikan Universitas Jembar https://jurnal.unej.ac.id/index.php/fkip-epro/article/view/4850/3573

Septiana, ika, Bambang Yulianto, and Kisyani Laksono. (2017). Declarative Sentence Spectrograph Produced by Autism Children. P. 364-371. International Conference on Teacher Training and Education (ICTTE 2017) https://www.atlantis-press.com/proceedings/ictte-17/25885808.

Subyantoro. (2013). Gangguan Berbahasa. Yogyakarta: Ombak.

Sudaryanto. (2015) Metode dan Aneka Teknik Analisis Bahasa. Yogyakarta:Sanata Dharma University Press.

Verhar, J.W.M. (2006). Asas-Asas Linguistik Umum. Yogyakarta: Gajah Mada University Press.

Yulianto, Bambang. (2009). Perkembangan Fonologi Bahasa Anak. Surabaya:Unesa University Press.

Zuchdi, Darmiyanti. (2009). Humanisasi Pendidikan. Jakarta:Bumi Aksara. 